Vol. 4, No. 1, 2018

Andriy Slipchuk ${ }^{1}$, Andriy Kuk ${ }^{2}$

${ }^{1}$ Department of Mechanical Engineering Technologies, Lviv Polytechnic National University, 12, S. Bandera Str., Lviv, Ukraine, E-mail: andsl@ukr.net

${ }^{2}$ Department of Mechanical Engineering Technologies, Lviv Polytechnic National University, 12, S. Bandera Str., Lviv, Ukraine, E-mail: Andrii.M.Kuk@1pnu.ua

\title{
EVALUATION OF THE PERMISSIBLE MOMENT IN A ROLLER CONE DRILL BIT PROVIDING THE RELIABILITY OF WORK
}

Received: December 07, 2018 / Revised: February 01, 2018 / Accepted: June 26, 2018

(C) Slipchuk A., Kuk A., 2018

Abstract. After analyzing the nature of the damage of surfaces was discovered the traces of the compression effect which arise along the cutters axis when squeezing it into the rock of delve. There were also founded the traces of deformation from the action of bending to the cutter, depending on the orientation of its slip on the face. We noticed the rubbing, fretting-corrosion, damage the local areas of the apertures walls caused by scrolling the cutter around its axis in the aperture of cones crown. In the case of the use of cutters with symmetrical aggravation of the rockdestructive part, the orientation of the generating line of active part of the cutter is determined by an effective angle to the axis of the crown of the cone. Calculations show that an angle of $45^{\circ}$ is optimal. We noticed the rubbing, fretting-corrosion, damage the local areas of the apertures walls caused by scrolling the cutter around its axis in the aperture of cones crown. The analysis of types of rock-destructive equipment of cones damages has been revealed that with increasing the magnitude of the axial load on the bit, cases of splitting, destruction of hard-alloyed cutters increase.

For this purpose, it is necessary to protect the drill's crowns from cementation. If carbide cutters are located in several rows in the cone drill, then milling of the sites on cemented layer's depth is effective. This prevents the removal of parts of cone's crown. The allowable moment is proportional to the square of the height, so the connections which perceive the considerable bending moments cannot be performed with small values of the diameter or small height of the cutter shank.

Keywords: tungsten carbide inset cutter, tension, connection "cone - tungsten carbide inset cutter", selective group, cone, insert rock-destructive equipment, drilling, drill bits.

\section{Formulation of the Problem}

Roller cone drill bits with hard-alloyed rock-destructive equipment have been widely used in the construction of wells of various purposes [1-5]. The production of such roller cone bits sets before the chisel construction a set of requirements for the selection of steel for them, parameters of carbon saturation and heat treatment, technological operations of molding of holes and drafting of the "inset cutter - cone" connection. The rock-destructive equipment with carbide inserted is exploited under difficult conditions and often fails due to imperfections in the design and technology of manufacturing roller cone bits. Therefore, studying the ways of improving a quality of inserted rock-destructive equipment at the stages of creating roller cone drill bits is an important and topical task of the bit construction [6].

Efficiency of drilling with roller cone bits in the majority is determined by quality indicators of rockdestructive equipment. For drilling solid, abrasive, durable and especially durable rocks the cones of such roller bits are used with rock-destructive equipment - hard-alloyed inset cutter. Roller tricone drill bits are used in extremely difficult conditions due to the effects of high dynamic loads, corrosive and abrasive medium, elevated temperatures and others. As a result, it equipment can be deteriorated due to: abrasive wear, cracking and breaking of parts of cone or tooth, dropping of carbide inserts, etc. At the same time, 
high-quality indicators of rock-destructive equipment are the most important not only because of high maintenance requirements for cone drilling bits, but also on their cost due to the use of valuable materials. This puts a set of requirements for materials, design, and technology for the production of rock-destructive equipment of roller cone bits. Note that these requirements are quite difficult and sometimes impossible to satisfy simultaneously. Therefore, there is a problem of increasing the quality indicators of the rockdestructive equipment of roller cone drill bits which is solved in different ways.

In recent years, the problem of improving and increasing the durability of inserted rock-destructive equipment has been given much attention in the works [1-7]. Much of the research is devoted to solving the problem of selection and development the materials for inset cutters [1-3]. There is also information about development of technology for the production of combined inset cutter [6,7]. The main approaches to improving the design of the insert rock-destructive equipment have been developed in order to increase the efficiency of drilling not long ago [8-11]. Nowadays, too much attention is paid to the improvement of the technology of pressing carbide inset cutters into cones [7, 11]. The analysis of these and many others works, as well as study of manufacturing roller cone drill bits at bit factory, shows that the problem needs to be solved in a comprehensive manner. Here is a well-proven process approach $[8,10,11]$, which allows at the before-production and production stages to solve a wide range of problems from united positions of sets of design, technological, functional and operational, economic indicators of quality. Nevertheless, there are a number of still unresolved interconnected tasks of optimization of physic and mechanical, design and technological parameters of the "inset cutter - cone" connection, as well as improvement of the technological processes of forming the holes for the tail part of hard-alloyed inset cutters and assembly operations. Problems of constructive perfection of tail part of inset cutters remain also debatable.

\section{Analysis of Recent Research and Publications}

As the rotor turns around the axis of the cutter, which deepened with its part into the rock, there are deformations and destruction of delves rock. While the next inset cutter entering the rock, the previous one turns the rock out [12]. After analyzing the type of wear and loss working of inset rock-destructive equipment there were ascertainments of the next facts: slacking; scrolling of cutters around their own axis; change in their orientation; breaking out and falling out of the hard-alloyed cutter. The instantaneous load on the cones cutters can reach $80-85 \%$ of the total load on the bit [13]. The process of cones drilling it is the destruction of the crushing and slipping effect on the rock delves. There is a sliding of equipment of cutters on the surface delves in the radial and tangential direction.

"Security DBS Dresser Industries Inc." has developed a bit that has equilibrium forces and balanced load dispersion [10]. In the design, the effect of the optimal orientation of rock-cutting equipment and the provision of conditions for preventing the formation of crests on the rock are realized. Destruction of the rock delves by hard-alloyed cutters causes a complicated tense state of the cutters body and the bodies of the cones crowns (Fig. 1). The rock-destructive equipment of cones which are based on hard-alloyed inset cutters with sharpened striking part undergoes bending and twisting loads.

The moment of torsion due to the axis of the cutter arises due to the nature of the movement of the cones, which causes a constant change in the orientation of the front plane of the working part of the insertion cutter. This gives the best effect in destroying the rock of delve. In the process of rotation of the cone, the rock-destructive cutters, which penetrated with an active part into the rock of delve, receive longitudinal and transverse loads. Loaded cutter performs relative due to its generating line longitudinal and transverse sliding. The forces of the reaction of delve cause a complex and tense state of the active and output from the body of the cutters parts. Different points of contact cutters with rock carry out uneven sliding. The forces of friction- scraping contribute to the occurrence of cutter twisting moment.

The penetration of active part of hard-alloyed inset cutters into the rock, as well as the rotational movement of the cone on delve, causes the appearance of tangential, bending and compressive stresses (Fig. 2). This reduces the strength of the "inset cutter - cone" connection a lot. At the point of contact of the conjugated surfaces there occurs micro siding, micro deformation and micro destruction. 


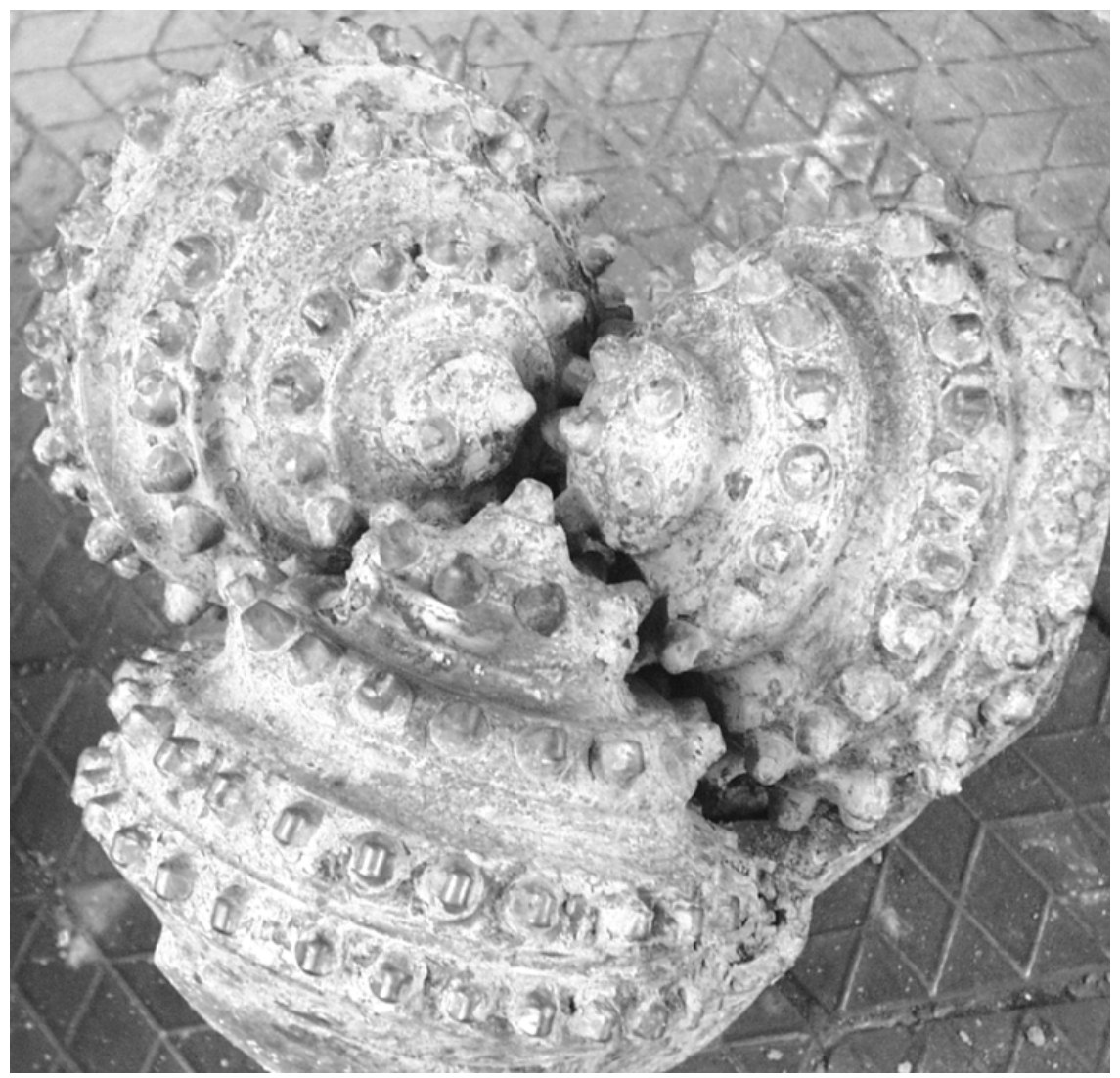

Fig. 1. Appearance of the destroyed roller three-cone drill bit

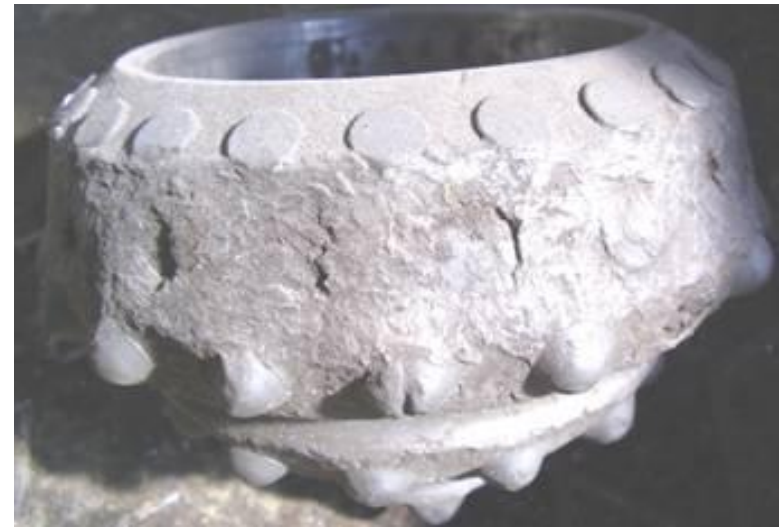

$a$

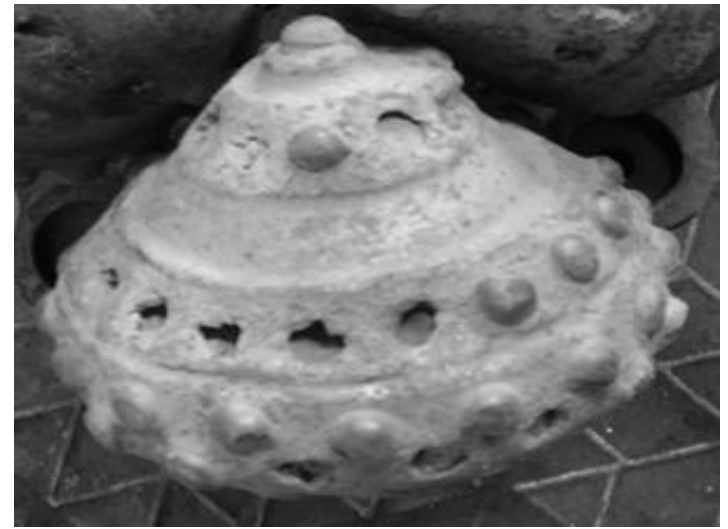

$b$

Fig. 2. Appearance of the destroyed roller cone drill bit 269,9 VS-PV with the most loaded crowns of cones: $a$ - the fall out and destruction of the rock-destructive part of hard-alloyed cutters and the rolled cones crown; $b$-falling out of the hard-alloyed cutters of cone

\section{Formulating the Aim of the Article}

After analyzing the nature of the damage of surfaces was discovered the traces of the compression effect which arise along the cutters axis when squeezing it into the rock of delve (Fig. 3). There were also founded the traces of deformation from the action of bending to the cutter, depending on the orientation of its slip on the face. We noticed the rubbing, fretting-corrosion, damage the local areas of the apertures walls caused by scrolling the cutter around its axis in the aperture of cones crown.

The analysis of types of rock-destructive equipment of cones damages has been revealed that with increasing the magnitude of the axial load on the bit, cases of splitting, destruction of hard-alloyed cutters increase. 


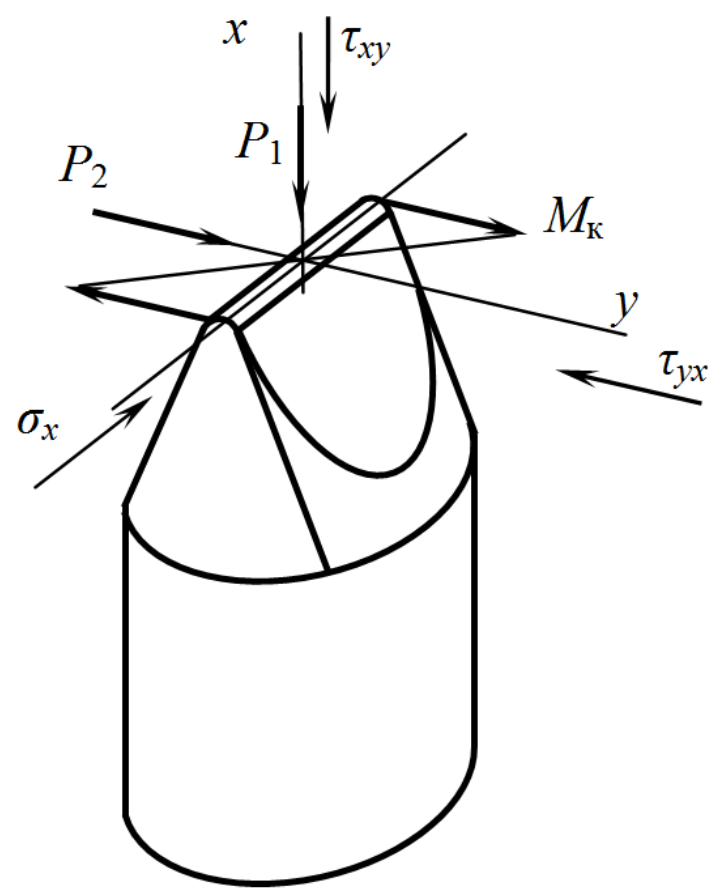

Fig. 3. The effect of tension on the top of hard-alloyed inset cutter

\section{Presenting the Main Material}

To analyze the type of the tensions, which arise in the hard-alloyed inset cutter, we will use the theory of resiliency [14] and advances in the field of mechanics material [15]. In the orientation of the active part of the hard-alloyed inset cutter along the generating line, there must be such tensions between the existing tensions:

$$
\left\{\begin{array}{l}
\frac{\partial \sigma_{x}}{\partial x}+\frac{\partial \tau_{x y}}{\partial y}=0 \\
\frac{\partial \sigma_{y}}{\partial y}+\frac{\partial \tau_{y x}}{\partial x}=0
\end{array}\right.
$$

In the case of the action on an arbitrary area of some tangent tension, a perpendicular to the site will necessarily have a tension, equal in magnitude and opposite to the sign [15]. According to the hypothesis of plane sections of the mechanics materials, we have the following calculation formulas:

$$
\left\{\begin{array}{c}
\sigma_{x}=-\frac{P_{1}}{2 x d_{3}}+\frac{P_{2} y\left(x-r_{0}\right)}{2 x^{3} d_{3}} \\
\sigma_{y}=0 ; \\
\tau_{x y}=\tau_{y x}=\frac{3 P_{2}\left(x^{2}-y^{2}\right)}{4 x^{3} d_{3}},
\end{array}\right.
$$

where $d_{3}$ - diameter of the rock-destructive hard-alloyed inset cutter; $r_{0}$ - radius of rounding of the active part of hard-alloyed inset cutter; $P_{1}-$ longitudinal force, which acting on the acting part of the cutter; $P_{2}-$ transverse force which acting on the acting part of the cutter.

Taking as a basis $\sigma_{x}$, we solve the system of equations (1) and (2). Because of:

$$
\frac{\partial \tau_{x y}}{\partial y}=-\frac{\partial \sigma_{x}}{\partial x}
$$


It turns out:

$$
\frac{\partial \tau_{x y}}{\partial y}=-\frac{P_{1}}{2 x^{2} d_{3}}+\frac{3 P_{2} y\left(2-\frac{3}{x} r_{0}\right)}{2 x^{3} d_{3}} .
$$

Integrating:

$$
\tau_{x y}=-\int \frac{P_{1}}{2 x^{2} d_{3}} d y+\int \frac{3 P_{2}\left(2-\frac{3}{x} r_{0}\right)}{2 x^{3} d_{3}} y d y .
$$

We will get:

$$
\tau_{x y}=-\frac{P_{1}}{2 x^{2} d_{3}} y+\frac{3 P_{2}\left(2-\frac{3}{x} r_{0}\right)}{4 x^{3} d_{3}} y^{2}+C,
$$

where $C=C_{1}+C_{2}$ - some integration function.

Assume that on the edges there is an ideal sliding, that is $x=y$ and $\tau_{x y}=\sigma_{x}$, so:

$$
-\frac{P_{1}}{2 x d_{3}}+\frac{P_{2} x\left(x-r_{0}\right)}{2 x^{3} d_{3}}=-\frac{P_{1}}{2 x^{2} d_{3}} x+\frac{3 P_{2}\left(2-\frac{3}{x} r_{0}\right)}{4 x^{3} d_{3}} x^{2}+C \text {. }
$$

Therefore:

$$
C=\frac{3 P_{2} r_{0}}{4 x^{2} d_{3}} .
$$

The calculation formula for the tangential stresses will have the form:

$$
\tau_{x y}=-\frac{P_{1}}{2 x^{2} d_{3}} y+\frac{3 P_{2} r_{0}}{4 x^{2} d_{3}}+\frac{3 P_{2}\left(2-\frac{3}{x} r_{0}\right)}{4 x^{3} d_{3}} .
$$

Whereas:

$$
\begin{gathered}
\frac{\partial \sigma_{y}}{\partial y}=-\frac{\partial \tau_{y x}}{\partial x} ; \\
\frac{\partial \tau_{y x}}{\partial x}=-\frac{P_{1}}{x^{3} d_{3}} y+\frac{3 P_{2} r_{0}}{2 x^{3} d_{3}}+\frac{9 P_{2}\left(1-\frac{2}{x} r_{0}\right)}{2 x^{4} d_{3}} y^{2} \\
\sigma_{y}=-\int \frac{P_{1}}{x^{3} d_{3}} y d y+\frac{3}{2} \int \frac{P_{2} r_{0}}{x^{3} d_{3}} d y+\frac{9}{2} \int \frac{P_{2}\left(1-\frac{2}{x} r_{0}\right)}{x^{4} d_{3}} y^{2} d y \\
\sigma_{y}=-\frac{P_{1}}{2 x^{3} d_{3}} y^{2}+\frac{3 P_{2} r_{0}}{2 x^{3} d_{3}} y+\frac{3 P_{2}\left(1-\frac{2}{x} r_{0}\right)}{2 x^{4} d_{3}} y+C_{3} .
\end{gathered}
$$

Taking the assumption assumed above, and equating the left-hand sides of equations (9) and (13), we obtain $C_{3}=0$.

Now the calculation formula for $\sigma_{y}$ will look like:

$$
\sigma_{y}=-\frac{y}{2 x^{3} d_{3}}\left(-P_{1} y+3 P_{2}\left(r_{0}+\frac{y^{2}}{x}\left(1-\frac{2}{x} r_{0}\right)\right)\right) \text {. }
$$


The resulting calculation tension is calculated according to the energy theory of strength:

$$
\sigma_{p}=\sqrt{\sigma_{x}^{2}-\sigma_{x} \sigma_{y}+\sigma_{y}^{2}+3 \tau_{x y}^{2}} .
$$

During the penetration of the rock-destructive part of the cutter into the delves rock, tensions are mainly concentrated at the top of the surface of the inset cutter. These cause the development of a wide range of designs of the active part of rock-destructive cutter. In particular, "Hughes Christensen Co." have developed one-sided sample inset cutters [10].

In the case of the use of cutters with symmetrical aggravation of the rock-destructive part, the orientation of the generating line of active part of the cutter is determined by an effective angle to the axis of the crown of the cone. Calculations show that an angle of $45^{\circ}$ is optimal. The exploitation of drill bits with such construction of rock-destructive equipment found an increase in the efficiency of the destruction the delves rock, which positively influenced on the rates of passage of the bit.

To ensure the reliability of the connection "insert cutter shank - cone aperture" from scrolling, we set the condition for setting the limit value of tension in the connection.

While landing a cutter there is a contact pressure $p$ and the corresponding force of friction, which operates on the elementary platform $d s=r h d \phi$ is equal:

$$
d p=p_{0} r h f d \phi
$$

where $r$ - radius of the shaft of inset cutter; $h$ - height of the shaft of the inset cutter, which is connected to the surface of aperture in the cone; $f$ - coefficient of friction in conjugation of contacting surfaces of the connection.

The moment of force relative to the axis of symmetry of the cutter is $d M_{\mathrm{T}}=p_{0} r^{2} h f d \phi$. Integrating this expression we obtain an expression for determining the moment of frictional forces

$$
d M_{\mathrm{T}}=p_{0} r^{2} h f \int_{0}^{2 \pi} d \phi=p_{0} r^{2} h f 2 \pi .
$$

To avoid scrolling, it is necessary to satisfy the condition $M_{\mathrm{T}}>M_{\mathrm{K}}$. Now we have:

$$
M_{\mathrm{K}}<2 \pi p_{0} h f r^{2} \text {. }
$$

The requisite pressure between the conjugated surfaces of the shank cutter and the aperture in the cone:

$$
p_{0}=\frac{M_{\mathrm{K}}}{2 \pi h f r^{2}} \text {. }
$$

On the other hand, using the formulas of Lame, we will get [15]:

$$
p_{0}=\frac{\Delta E}{(A+B) d_{3}} \text {. }
$$

where $\Delta$ - tension in the connection; $E$ - modulus of elasticity; $d_{3}$ - diameter of the shank cutter; $A+B=\frac{0,5 b^{2}}{0,25 b^{2}-r^{2}} ; b-$ thickness of the rolled cones crown in which the aperture for the cutters are made.

Consequently, the value of tension in the connection must satisfy the condition:

$$
\Delta \geq \frac{0,5 M_{\mathrm{K}} b^{2}}{\pi E h f\left(0,25 b^{2}-r_{3}^{2}\right) r_{3}} .
$$

Proceeding from the data presented in [16], we consider the conditions to provide the reliability of the connection "insert cutter shank - cone aperture" from the bending moment to the cutter.

When loading the connection by the bending moment $\mathrm{M}$ on the uniform diagram of pressure from the landing superimposes the pressure diagram, characteristic for the bend. At the same time, $0,5 \mathrm{M}$ acting 
on an active part of the cutter. The same magnitude of the moment acting on the opposite side of the base of shank of the cutter.

Based on classical approaches we will have the pressure:

$$
p_{1}=\frac{4}{\pi} \frac{M}{2 W}=\frac{12 M}{\pi d h^{2}} \leq p
$$

where $\frac{4}{\pi}$ - factor, which takes into account the character of the pressure diagram on the circumference of the shaft of the inserted cutter; $W=\frac{d h^{2}}{6}-$ moment of resistance of bend of shank section.

The value of the allowable moment to ensure the reliability of the connection "insert cutter shank cone aperture" can be accepted:

$$
M=0,2 p d h^{2} .
$$

Let's put it $p_{1}=0,75 p$.

Based on the formulas of material resistance, the fixed pressed joint is provided by creation of a tension with corresponding distribution of strain in the body of cutter and the conjugated layers of the rolling cone drills body. Therefore, the influence of mechanical indicators of cutters and rolling cone drills material on the magnitude of contacts forces and tension together was estimated on Lame's formulas [15]:

$$
p_{\kappa}=\frac{N}{d_{3}}\left(\frac{1-\mu_{3}}{E_{3}}+\frac{1+\mu_{u}}{E_{u}}\right)^{-1},
$$

where $d_{3}$ - diameter of the cutter (mm); $N$ - tension while the cutter landing cone drill $(\mathrm{mm}) ; \mu_{3}-$ Poisson coefficient for material of shank cutter (for solid alloy 0.24); $\mu_{u}$ - Poisson coefficient for cone drills steel scales $(0.3) ; E_{3}$ - modulus of elasticity for material of shank cutter (5.6 $\left.105 \mathrm{MPa}\right) ; E_{u}-$ modulus of elasticity for material of rolling cone $(5.6 \cdot 105 \mathrm{MPa})$.

Calculate the contact pressure that occurs when the cutter is pressed at the maximum tension $N_{\max }=0.167 \mathrm{~mm}$

$$
p_{\kappa}=\frac{N}{d_{3}}\left(\frac{1-\mu_{3}}{E_{3}}+\frac{1+\mu_{u}}{E_{u}}\right)^{-1}=\frac{0,167}{12}\left(\frac{1-0,24}{5,6 \cdot 10^{5}}+\frac{1-0,3}{2,1 \cdot 10^{5}}\right)^{-1}=2967 \mathrm{MPa},
$$

and the minimum $N_{\min }=0.111 \mathrm{~mm}$

$$
p_{\kappa}=\frac{N}{d_{3}}\left(\frac{1-\mu_{3}}{E_{3}}+\frac{1+\mu_{u}}{E_{u}}\right)^{-1}=\frac{0,111}{12}\left(\frac{1-0,24}{5,6 \cdot 10^{5}}+\frac{1-0,3}{2,1 \cdot 10^{5}}\right)^{-1}=1972 \mathrm{MPa} .
$$

According to the performed research, we will now conduct an analysis of the strength of chisel's cone with a diameter of $302 \mathrm{~mm}$, which undergoes tensions when the cutter is pressed on a simulated cone in the CAE of the KOMPAS-3D V16 system (Figs. 4 and 5).

\section{Conclusions}

The conducted studies allowed to establish the nature of distribution of contacted tenses in the conjugated areas "shank of the cutter - cones hole", which are shown in the figure (Pic. 5). Preventing the appearance of cracks at the stage of pressing cutter can be achieved by creating favorable tensions in the surface of hole in the cone drill's crown. For this purpose, it is necessary to protect the drill's crowns from cementation. If carbide cutters are located in several rows in the cone drill, then milling of the sites on cemented layer`s depth is effective. This prevents the removal of parts of cone`s crown.

The allowable moment is proportional to the square of the height, so the connections which perceive the considerable bending moments cannot be performed with small values of the diameter or small height of the cutter shank. 
In the following practical interest is the need to simulate the variants of distribution the tension (contact pressures) with various indicators of roughness of the conjugated parts, as well as variants of tension distribution (contact pressures) in the crown of the roller cone at different distances from each other of hard-alloy insert cutters.

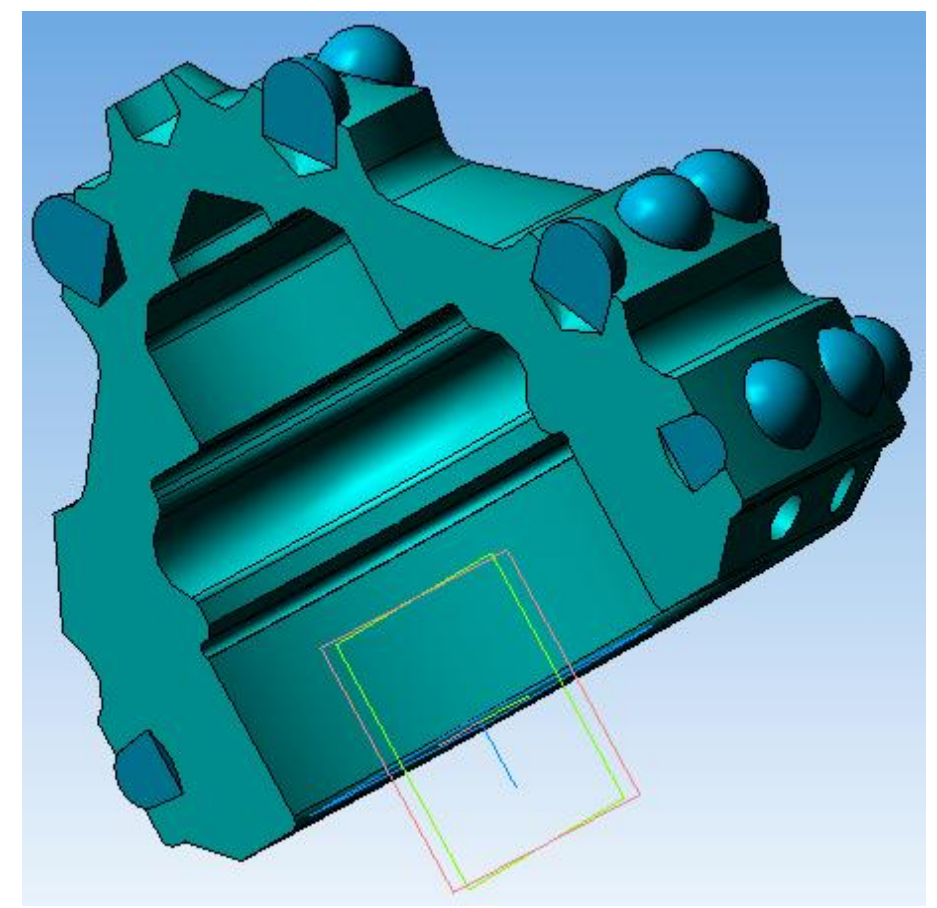

Fig. 4. 3-D model of three-bore rolling cutter drill's cone, diameter $302 \mathrm{~mm}$

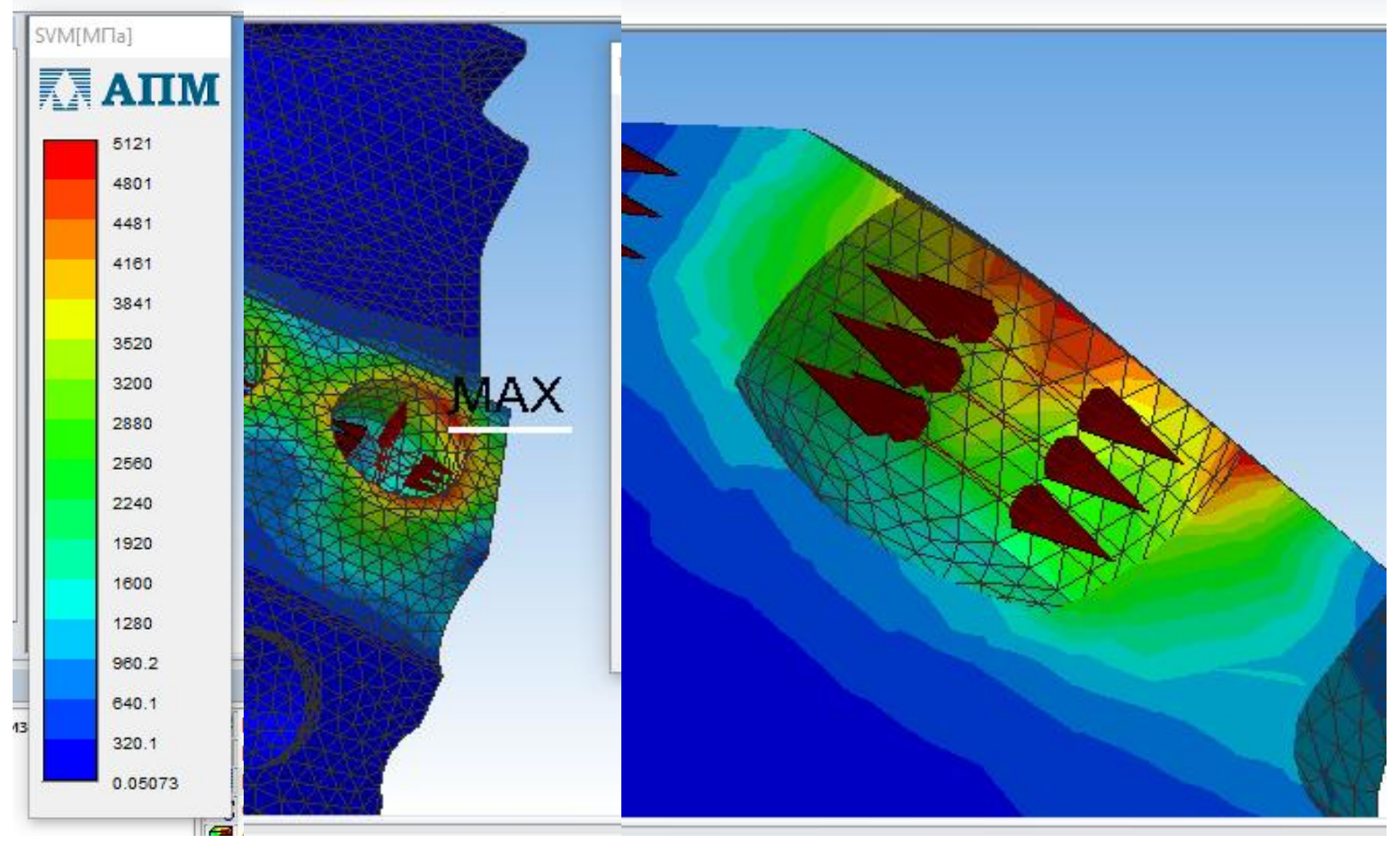

Fig. 5. Enlarged view of conjugation "shank of the cutter - cone`s hole" of the chisel with diameter $302 \mathrm{~mm}$, with a cut of a strained state at tension 167 microns 


\section{References}

[1] G. L. Doll, R.D. Evans, and C. R. Ribaudo, Improving the performance of rolling contact bearings with tribological coatings", in Surface Engineering in Materials Science III. Warrendale, PA: TMS Publ., 2005, pp. 153-162.

[2] Zhiqiang Huang, et al., "Experimental research on the surface strengthening technology of roller cone bit bearing based on the failure analysis", Engineering failure analysis, vol. 29, pp. 12-26, 2013.

[3] Deng Yong, et al., "Theoretical and experimental study on the penetration rate for roller cone bits based on the rock dynamic strength and drilling parameters", Journal of natural gas science and engineering, vol. 36, pp. 117-123, 2016.

[4] J. Schroder, et al., "Bearing innovations extend roller-cone bit life", Oil \& gas journal, vol. 114, issue 6, pp. 50-55, 2016.

[5] Naganawa Shigemi, "Feasibility study on roller-cone bit wear detection from axial bit vibration", Journal of petroleum science and engineering, vol. 82-83, pp. 140-150, 2012. [in Russian].

[6] R. S. Yakym, and A. M. Slipchuk, "Vdoskonalennia tekhnolohii vyhotovlennia burovykh dolit z vstavnym porodoruinivnym osnashchenniam na etapi proektuvannia protsesu presuvannia tverdosplavnykh vstavok u sharoshku" ["Improvement of the technology of manufacturing drill runners with inserted rock-cutting equipment at the stage of designing the pressing process of carbide inserts in a scroop"], Visnyk Natsionalnoho universytetu "Lvivska politekhnika": Optymizatsiia vyrobnychykh protsesiv i tekhnichnyi kontrol u mashynobuduvanni ta pryladobuduvanni [Bulletin of Lviv Polytechnic National University: Optimization of production processes and technical control in mechanical engineering and instrument making], no. 822, pp. 86-91, 2015. [in Ukrainian].

[7] A. M. Slipchuk, and R. S. Yakym, "Pokrashchennia yakosti tekhnolohii protsesu zapresovuvannia zubtsiv u sharoshky burovykh dolit" ["Improvement of the quality of technology of the process of squeezing the teeth into the rollers of the drill valleys"], Visnyk Natsionalnoho universytetu "Lvivska politekhnika": Optymizatsiia vyrobnychykh protsesiv $i$ tekhnichnyi kontrol u mashynobuduvanni ta pryladobuduvanni [Bulletin of Lviv Polytechnic National University: Optimization of production processes and technical control in mechanical engineering and instrument making], no. 867, pp. 69-77, 2017. [in Ukrainian].

[8] V. G. Neupokoev, Voprosy teorii i praktiki proektirovaniia, proizvodstva $i$ ekspluatatcii burovykh sharoshechnykh dolot [Questions of the theory and practice of design, production and operation of roller bits]. Samara, Russia: Izdatelstvo Samarskogo nauchnogo tcentra Rossiiskoi akademii nauk, 2000. [in Russian].

[9] L. V. Morozov, "Povyshenie dolgovechnosti burovykh dolot na osnove kompiuternogo analiza elementov konstruktcii i ikh sborki" ["Scientific fundamentals of development of energy-saving inter-resonance vibratory machines"], PhD dissertation, Samara State Technical University, Samara, Russia, 2003. [in Russian].

[10] R. S. Yakym, and A. M. Slipchuk, "Konstruktorsko-tekhnolohichni pidkhody u vyznachenni optymalnoho rozmishchennia zubkiv na vintsiakh sharoshok trysharoshkovykh burovykh dolit" ["Design and technological approaches in determining the optimal placement of teeth on the coils of the three-pile trench drill bits"], Visnyk Natsionalnoho tekhnichnoho universytetu "KhPI": Tekhnolohii v mashynobuduvanni [Bulletin of the National Technical University "KhPI": Technologies in mechanical engineering], no. 5 (1177), pp. 25-33, 2016. [in Ukrainian].

[11] A. M. Slipchuk, and R. S. Yakym, "Pokrashchennia yakosti tekhnolohii protsesu zapresovuvannia zubkiv u sharoshky burovykh dolit" ["Improvement of the quality of technology of the process of pressing the teeth in the chopper drill bits"], Vysoki tekhnolohii v mashynobuduvanni [High technologies in mechanical engineering], vol. 1 (27), pp. 134-141, 2017. [in Ukrainian].

[12] R. Lord, "Novye dostizheniia v tekhnologii proizvodstva burovykh dolot" ["New advances in the technology of production of drill bits"], Neftegazovye tekhnologii [Oil and Gas Technologies], no. 3, pp. 44-49, 2006. [in Russian].

[13] S. V. Sinev, "Razrushenie gornykh porod vooruzheniem sharoshechnogo dolota" ["The destruction of rocks by the armament of a roller bit"], Nauka $v$ neftianoi i gazovoi promyshlennosti [Science in oil and gas industry], no. 1, pp. 8-12, 2010. [in Russian].

[14] H. S. Pysarenko, O. L. Kvitka, and Ye. S. Umanskyi, Opir materialiv [Strength of materials]. Kyiv, Ukraine: Vyshcha shkola Publ., 2004. [in Ukrainian].

[15] D. N. Reshetov, Detali mashin [Machine parts]. Moscow, Russia: Mashinostroenie Publ., 1989. [in Russian].

[16] S. P. Timoshenko, and Dzh. Gudier, Teoriia uprugosti [Elasticity theory]. Moscow, Russia: Nauka Publ., 1979. [in Russian]. 